\title{
O Novo Plano de Treinamento para - Serviço Público
}

recente decreto 43.176 , que institui a Escola de Serviço Público, vinculada aos Cursos de Administração do D.A.S.P., deve ser saudado como um passo decisivo no sentido de ampliar as bases do programa de aperfeiçoamento do funcionalismo público civil.

A primeira conseqüência prática dêsse ato é a colocação do problema do treinamento de pessoal para os serviços públicos na órbita do Ministério da Educação e Cultura, o que importa no reconhecimento dêsse ramo do ensino especializado como parte integrante do sistema oficial de educação.

Daqui por diante, ao invés de constituir simples atividade supletiva e forma de cooperação prestada por instituições não tìpicamente educacionais, como o D.A.S.P., ou por entidades de ensino mantidas pela iniciativa particular, a preparação de pessoal para a administração pública passa a constituir função normal do Ministério da Educação e Cultura.

Dessa forma, a vasta aparelhagem montada por êsse Ministério, a grande experiência por êle acumulada ao longo dos anos, os recursos provenientes de suas ligações no campo internacional, por fôrça dos programas de cooperação e ajuda mútua entre países, serão postos a serviço de um problema, cujas exigências se tornam cada vez mais imperiosas.

Através do entrosamento das possibilidades do D.A.S.P., como órgão especializado em questões de administração geral, e as do Ministério de Educação e Cultura, como órgâo de administração especifica, atingiu-se a uma fórmula fàcilmente exeqüível de suplementar o ensino educacional comum, pela introdução, nos seus níveis médio e superior, de cursos até aqui não contemplados nos planos oficiais. 
Uma das mais antigas aspirações do funcionalismo sediado no interior poderá agora vir a ser concretizada, mediante a descentralização dos cursos de treinamento, cuja atuação benemérita, por deficiência de recursos materiais, durante muitos anos se viu limitada ao Distrito Federal, fato que impedia a valorização dos respectivos diplomas para atribuição de certas vantagens aos seus portadores, uma vez que êstes eram beneficiários de oportunidades que a administração não estava em condições de assegurar a todos os seus servidores, conforme impunha o regime único de direitos e regalias consagrado pelo estatuto.

Outro grande benefício que o funcionalismo do interior poderá alcançar é o que advirá da criação de bôlsas de estudo, que the franquearão o acesso a centros de cultura mais adiantados, e the permitirão fecundar seus conhecimentos pelo contato com a experiência de organizações mais evoluídas.

Inicialmente, foram previstas vinte bôlsas: seis para aperfeiçoamento no exterior e quatorze para estágio no D.A.S.P., garantindo-se, em ambos os casos, criteriosa seleção de candidatos.

Mas não vamos ficar no terreno do puro elogio, pois entre as expressões de louvor ao plano que se pretende executar cabem algumas sugestões e algumas palavras de advertência, sem as quais estas breves considerações nenhuma contribuição ofereceriam.

Antes de mais nada, parece-nos conveniente lembrar a elaboração de uma bibliografia especializada que dê às atividades de treinamento possibilidades de maior penetração e de mais amplo rendimento. Para essa tarefa devem ser convocados os especialistas nos diferentes assuntos de interêsse do serviço público, cabendo à administraçâo oferecer-lhes condições que assegurem ao trabalho intelectual a situação de dignidade com êle compativel. Êste aspecto da questão não deve ser negligenciado, já que nenhum plano de treinamento pode merecer confiança, ou atuar como instrumento de estímulo ao estudo, se dentro dêle os elementos de cultura não forem devidamente prestigiados. Por outro lado, quem tem contato com o ensino técnico-especializado no Brasil sabe até que ponto vem sendo êle retardado pela deficiência do livro didático em idioma nacional.

Problema que também merece ser focalizado e para o qual há que reclamar o máximo de escrúpulo é o da escolha dos professôres. Embora nessa matéria os Cursos de Administração do 
D.A.S.P. possuam uma honrosa tradição, não é demais insistir na advertência, dadas as modificações que o decreto 43.173 introduziu no aparelhamento destinado à preparação de pessoal para os serviços públicos. No particular é imperioso não esquecer que a autoridade de que gozam os Cursos de Administração do D.A.S.P. é fruto da dedicação e do esfôrço de uma equipe que os vem servindo há longos anos e que agora, mais do que nunca, se torna necessária. Os elementos que a ela vierem juntar-se deverão ser esco1hidos dentro do mesmo espírito de respeito aos interêsses exclusivos do ensino.

Finalmente, uma vez que se torna possivel estender ao interior do país as atividades de treinamento dos servidores públicos, impõe-se pensar nas compensações a serem concedidas aos funcionários que, atendendo aos apelos da administração, vierem a preparar-se para o melhor desempenho de suas atribuições. Tais funcionários, na hora da partilha das vantagens, não poderão ser nivelados àqueles que, por indiferença ou comodismo, tiverem desprezado os meios de aperfeiçoamento que a administração, generosamente, thes ofereceu. 